\title{
QUALITY PROPERTIES CHANGES OF EGGPLANT DURING MICROWAVE-OVEN DRYING
}

\author{
Elsisi, S. F., (a) Taha, A. T., ${ }^{(b)}$ and Eissa, A. H. A. ${ }^{\text {(c) }}$
}

\begin{abstract}
Eggplant was dried under different microwave power and sample thicknesses to study their effect on quality properties (color parameters (L, a and $\Delta E)$, browning index and firmness) of eggplant slices. Eggplant slices were dried by microwave using microwave powers $(450 \mathrm{~W}, 630 \mathrm{~W}$ and $810 \mathrm{~W}$ ) and 0.5, 1, 1.5 and $2 \mathrm{~cm}$ of eggplant thicknesses. The results showed that, the higher L value was 43.23 occurred when drying eggplant slices with thickness $0.5 \mathrm{~cm}$ and microwave oven power 450 watt at $2.29 \%$ moisture content before burning. The higher a value was 13.66 occurred when drying eggplant slices with thickness $2 \mathrm{~cm}$ and microwave oven power 810 watt at $2.07 \%$ moisture content before burning. The $\Delta E$ varied from 5.54 to 33.09 at $0.5 \mathrm{~cm}$ of eggplant slices thicknesses and 450 Watt of microwave power. The higher (BI) value was 573.98 occurred when drying eggplant slices with thickness $2 \mathrm{~cm}$ and microwave oven power 810 watt. The higher and the lower final firmness value were 41.3 $N$ and $28.45 N$ occurred when drying eggplant slices at thickness 0.5 and $2 \mathrm{~cm}$ and microwave oven power 450 watt respectively.
\end{abstract}

Keywords: browning index, Eggplant, firmness, quality properties.

\section{INTRODUCTION}

$\mathrm{T}$ The global production of eggplants was 49.4 million tones. India (27\% of world total), Iran, Egypt and Turkey were also central producers that, combined with other Asian countries, comprise 94\% of world production. Egypt production was 1.2 million of tones FAOSTAT. (2013). Eggplant has a very limited shelf life for freshness and physiological and morphological changes occur after harvest. It is common to dry eggplants to extend shelf lives. By drying, moisture content is reduced to a level which allows safe storage over an extended period Doymaz (2011).

\footnotetext{
(a)Lecturer, ${ }^{(b)}$ Associated professor, ${ }^{(c)}$ professor of Agricultural Engineering Department, Menoufia University.
} 
Dried eggplant can be used as an ingredient in different kinds of meals, instant soups and sauces. Recently, there have been many researches about drying of eggplants Cruz, and Menegalli (2004) and Ertekin, and Yaldiz (2004). The eggplant was with hot air and investigated the effects of air temperature and sample thickness on the drying kinetics of samples. It was reported that while drying time of thinner slice of eggplant (diameter: $0.5 \mathrm{~cm}$ ) was $375 \mathrm{~min}$, drying time of thicker one (diameter: 1 $\mathrm{cm})$ was 495 min Doymaz and Gol (2011). In addition, as drying temperature was increased from $50^{\circ} \mathrm{C}$ to $80^{\circ} \mathrm{C}$, drying time was reduced from $330 \mathrm{~min}$ to $150 \mathrm{~min}$, respectively. Similarly, Ertekin, and Yaldiz (2004) tested drying characteristics, drying time and quality of eggplants which were dried in a laboratory hot air dryer. The results showed that increasing drying air temperature decreased the color lightness and increasing drying air velocity increased both color lightness. The eggplant was dried with vacuum drying technique. It was found that although shrinkage of the eggplants increased with an increase in drying chamber pressure, it was not dependent on drying temperature Wu, et al. (2007). Microwave related drying can meet the four major requirements in drying of foods: speed of operation, energy efficiency, cost of operation, and quality of dried products Gunasekaran (1999). The increased demand for plant-origin foods in fast-dehydrated form has increased interest in microwave-assisted dehydration Zhang and $\mathbf{X u}$ (2003). Appearance is one of the most important sensory quality attributes of fresh and processed food, products and their marketing Costa et al. (2011); Grossman and Wisenblit (1999). During hot air drying, food is exposed to heat for longer time that causes problems related to quality parameters such as unacceptable color, flavor, texture, sensory characteristics, loss of nutrients, shrinkage, reduction in bulk density and rehydration capacity Maskan (2001a). Drying process conditions effected on texture, appearance, color, flavor, taste and nutritional value. While drying conditions has been selected, type of feed, moisture content, drying kinetics, heat sensitivity, physical properties of the material to be dried and quality requirements of a dried food should be regarded Jangam (2011). Color is one of the most relevant attributes with respect to the quality of dried foods Bonazzi and Dumoulin (2011). The color of food 
surface is the first quality parameter evaluated by consumers, and it is critical to product acceptance. Food appearance determined mostly by surface color is the first sensation that the consumer perceives and uses as a tool to either accept or reject food Leon, et al. (2006). Other than browning, many reactions can affect color during thermal processing of fruits and vegetables. Among them, the most common is pigment degradation, especially carotenoids and chlorophyll and chemical oxidation of phenols and ascorbic acid. In general, longer drying times and higher drying temperatures produce greater pigment losses Mongi (2013). Browning in foods is of two types: enzymatic and non-enzymatic. Enzymatic browning is one of the most important reactions that occur in fruits and vegetables, usually resulting in negative effects on color, taste, flavor, and nutritional value Guerra, et al. (2010). It is an all-inclusive term involving size, shape, texture, mass, gloss, color and others Leon, et al. (2006). Firmness of horticulture products, as measured by mechanical methods, is frequently used to determine their maturity and ripeness Deell, et al. (2001). Firmness is a good measure of maturity and for many fruit, and vegetables. However firmness in the laboratory does not invariably translate into good mouth-feel or texture. It is a complex phenomenon based on the physical characteristics of cells Travers (2013). During drying process, the rate of evaporation is faster than the rate of water movement to the surface. Thus, the outer skin is too dry which is called "case hardening" and it is a significant problem in vegetable drying Vadivambal and Jayas (2007). The main goal of this work was to evaluate using the Microwave oven in Eggplant drying through, 1) Study the effect of microwave power and samples thickness on drying characteristics and quality parameters of Eggplants in terms of color and firmness. 2) Determine quality of eggplant slices before burning.

\section{MATERIALS AND METHODS}

The used Eggplants (Solanum melongena L.) in this study were collected from private farm. The samples were washed by water, peeled, and cut into slices, having a thickness of about $0.5,1,1.5$, and $2 \mathrm{~cm}$ using a kitchen slicer. Diameters of the eggplant's samples were $50 \pm 2 \mathrm{~mm}$. The 
eggplants samples drying was done using microwave oven (KOR-9G2B) using three different levels of the maximum oven output of $900 \mathrm{~W}$ and $2450 \mathrm{MHz}$, which were $50 \%, 70 \%$, and $90 \%$ of microwave power (450, 630 and $810 \mathrm{~W}$ ) respectively. In each case, 16 samples of Eggplant (with covering about $90 \%$ of the whole diameter of microwave rotary tray) were arranged in the microwave oven in order to dry until the final moisture content as shown figure 1 . The moisture content of eggplant was found to be about 93\%. according to the method approved by the (AOAC, 1980). The samples of eggplants slices were placed into the oven at $70{ }^{\circ} \mathrm{C}$ and left 24 hours. After this period, the samples were collected and placed into the desiccator to avoid gaining moisture from the atmosphere and left after cooling down, and then the samples were weighed again through the equation 1 .

$$
\mathrm{M}_{\mathrm{wb}}==\frac{\boldsymbol{w}_{\boldsymbol{o}}-\boldsymbol{w}_{\boldsymbol{d}}}{\boldsymbol{w}_{\boldsymbol{o}}} * 100, \%
$$

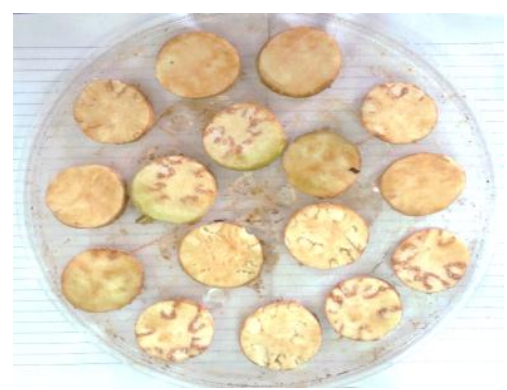

Figure 1. Arrangement of the Eggplant samples in the Microwave rotary tray.

For the duration of drying experiments, where weight losses are recorded, the instantaneous moisture contents at any given time $\left[M_{t w b}\right]$ can be computed according to the following equation 2 (Mohamed et al., 2010):

$$
M_{t w b}=1-\left(\frac{\left(1-M_{o w b}\right) * W_{o}}{W_{t}}\right) \%
$$

Where: -

$W_{o}=$ initial weight of fresh product, $\mathrm{kg}$

$W_{t}=$ weight of product at time ( $\left.\mathrm{t}\right), \mathrm{kg}$.

$M_{\text {owb }}=$ Original moisture content of eggplant (93\%)

To study the effect microwave drying on eggplant slices, Firstly the color measurement and the firmness of each sample was recorded every three 
minutes until the burning point of the samples. Secondly, Re-dry another sample even before the last three minutes of the previous time measured in its color measurement and the firmness, was recorded every minute until the burning point of the samples. Thirdly, Re-dry another sample even before the last minute of the previous time measured in its color measurement and the firmness, was recorded every 10 seconds until the burning point of the samples. The experimental treatments were replicated three times.

\subsection{MEASURMENTS:}

\subsubsection{Color measurement}

Color of the eggplant samples was measured using a WR-10 Colorimeter on its surface at each predetermined level of moisture content during drying as shown figure 2 . The $\mathrm{L}$, a and $\mathrm{b}$ indexes were used to evaluate the color change of the eggplant during drying. The $\mathrm{L}$ (lightness: $\mathrm{L}=0$ for black, $L=100$ for white), $a<0$ for green, $a>0$ for red) and $b$ (yellownessblueness: $b<0$ for blue, $b>0$ for yellow) according to the CIELAB (Commission Internationale de l'éclairage, L, a, b) colorimetric system keshek et al (2017). The average color parameters of fresh eggplant were used as a reference $(\mathrm{L}=73.23, \mathrm{a}=-0.212, \mathrm{~b}=19.73)$. The change in the surface color of the sample, which was referred to as the total color difference. Then, the total color difference $(\Delta \mathrm{E})$ and browning index $(\mathrm{Bi})$ were determined using the following equations (3), (4) and (5) keshek, et al. (2017):

$$
\begin{aligned}
\Delta \mathrm{E} & =\sqrt{(\Delta \mathrm{L})^{2}+(\Delta \mathrm{a})^{2}+(\Delta \mathrm{b})^{2}} \\
\mathrm{Bi} & =\frac{[100(\mathrm{x}-0.31)]}{0.17} \\
\mathrm{x} & =\frac{(\mathrm{a}+1.75 \mathrm{~L})}{(5.645 \mathrm{~L}+\mathrm{a}-3.012 \mathrm{~b})}
\end{aligned}
$$

\subsubsection{Firmness determination}

Firmness of eggplant slices was determined by FHT-1122 hardness tester and related with quill diameter of $3.5 \mathrm{~mm}$ were pressed eggplant slices until penetration and then record the reading device as shown figure 3 . Firmness of the eggplant was measured based on the resistance of the flesh of an eggplant to deformation by the plate. 

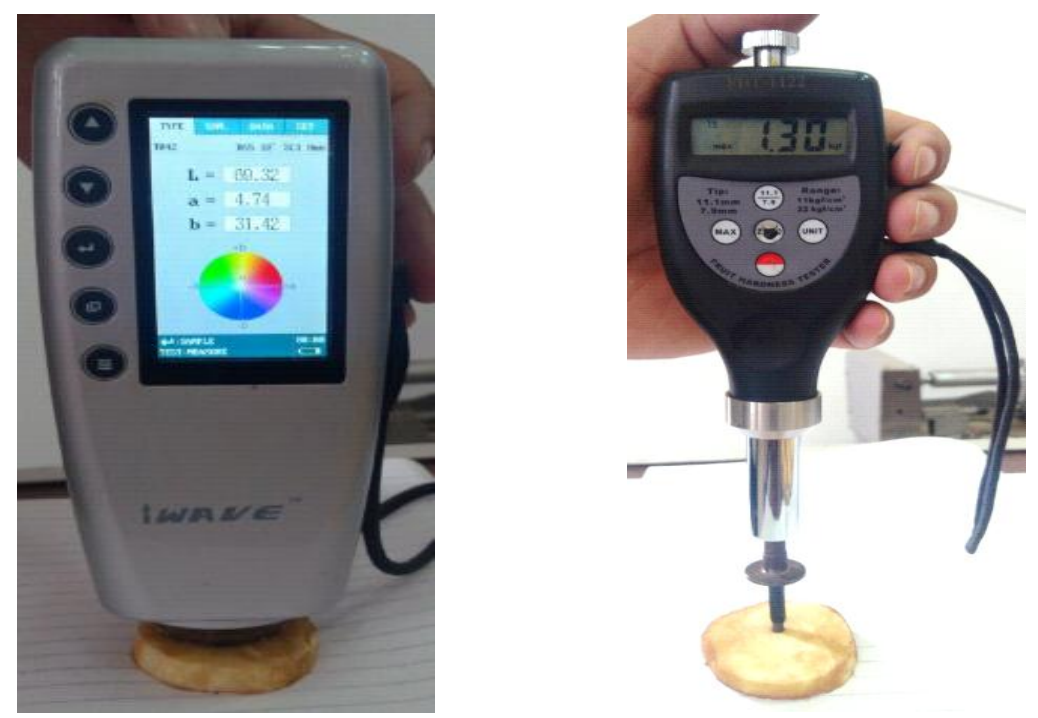

Figure 2: WR-10 Colorimeter. Figure 3: Hardness Tester, FHT-1122

\section{RESULTS AND DISCUSSION}

\subsection{Drying kinetics of eggplant samples.}

The initial moisture content of the eggplant slices was around $93 \%$ wet basis (13.28 g water/g dry matter). The table (1) present the moisture contents of the eggplant slices and drying time after the drying process in microwave oven and before burning directly for different powers and thicknesses of the eggplant slices.

Table (1): Eggplant slices moisture content (\% w. b) and drying time after drying by the microwave with different powers and different thicknesses.

\begin{tabular}{|c|c|c|c|c|c|c|c|c|c|c|c|c|}
\hline $\begin{array}{c}\text { Microwave } \\
\text { power [Watt] }\end{array}$ & \multicolumn{3}{|c|}{450} & \multicolumn{3}{c|}{630} & \multicolumn{4}{c|}{810} \\
\hline $\begin{array}{c}\text { Slices thickness } \\
\text { [cm] }\end{array}$ & 0.5 & 1 & 1.5 & 2 & 0.5 & 1 & 1.5 & 2 & 0.5 & 1 & 1.5 & 2 \\
\hline $\begin{array}{c}\text { Drying time } \\
\text { [min] }\end{array}$ & 13.6 & 20.7 & 26.8 & 32.3 & 10.5 & 12.6 & 15.7 & 19.8 & 8.5 & 10.6 & 13.6 & 14.8 \\
\hline $\begin{array}{c}\text { Final moisture } \\
\text { content [\%] }\end{array}$ & 2.29 & 2.17 & 1.56 & 1.25 & 0.036 & 0.038 & 0.05 & 0.016 & 0.039 & 0.029 & 0.023 & 0.02 \\
\hline
\end{tabular}

\subsection{Effect of drying on color properties of eggplant slices}

The effects of microwave powers on the ( $L$ and a) values were represented in Figures 4 and 6. The values of color parameter L decreased with decreasing moisture content during drying process of the eggplant. While the values of (color parameter a) increased with decreasing 
moisture content during drying process of the eggplant. It was announced that, the reason could be inactivation of enzymes for enzymatic browning and reduced non-enzymatic browning due to the lower water activity. The value of L index was change from 73 of eggplant slices thicknesses 0.5 $\mathrm{cm}$ and microwave power $450 \mathrm{~W}$ (this is the lowest value in change compared to the fresh sample) to 43.23 also, the (a index) value increased from -0.212 to 9.85 at the same thickness and microwave power.

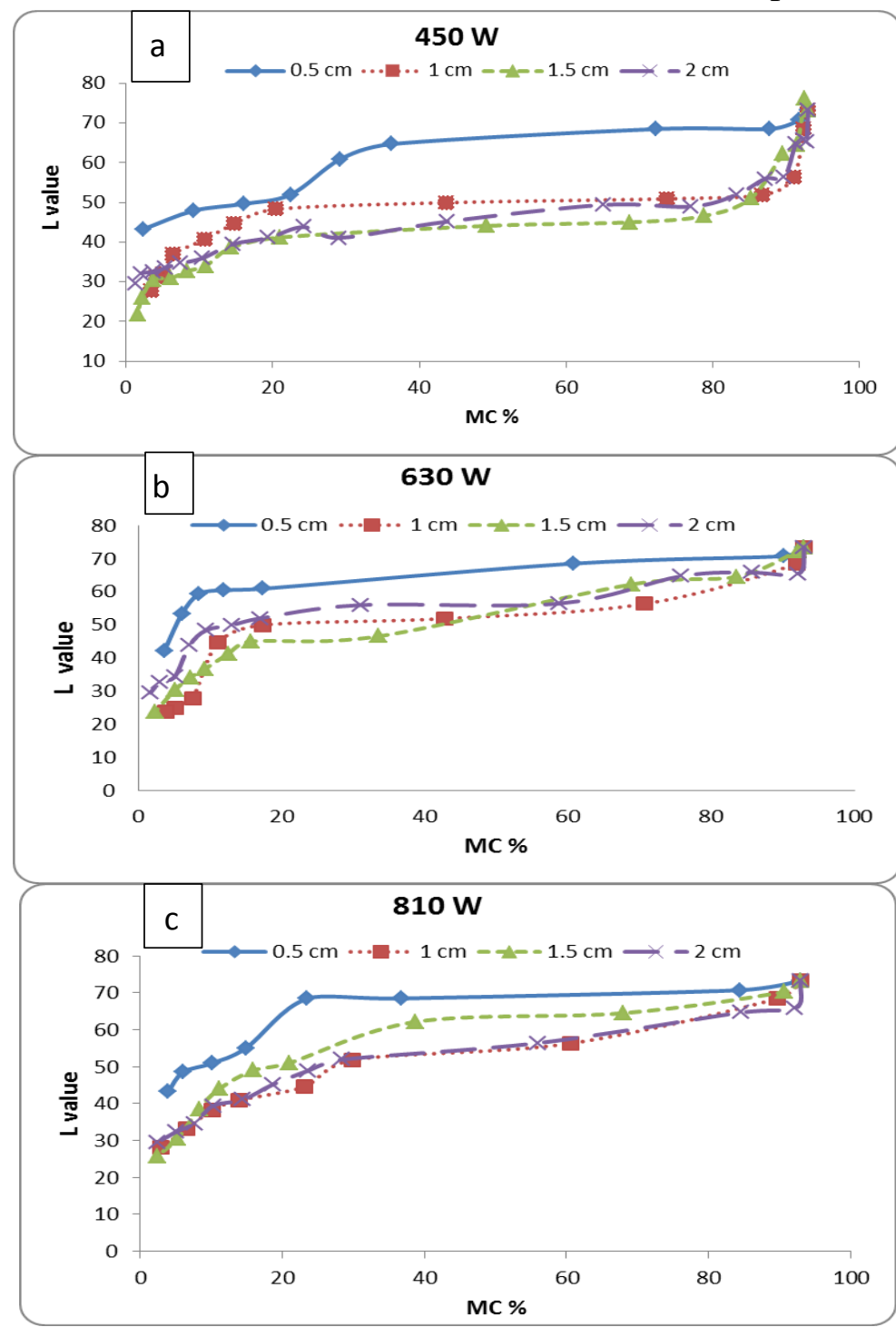

Figure 4 (a, $b$ and c): Effect of microwave power on $L$ value of dried eggplant with different thickness $(0.5,1.0,1.5$ and $2.0 \mathrm{~cm})$. 
Figure (5) Effect of microwave power on final $\mathrm{L}$ value at final moisture content of dried eggplant with different thickness $(0.5,1.0,1.5$ and 2.0 $\mathrm{cm}$ ), from this figure we can obtained that the L value gradually decrease by increasing in thickness when use microwave oven at all selected powers, whilst the $\mathrm{L}$ value was higher at the lower power and decrease by increasing in microwave power. The higher $\mathrm{L}$ value was 43.23 occurred when drying eggplant slices with thickness $0.5 \mathrm{~cm}$ and microwave oven power 450 watt, but the lower $\mathrm{L}$ value was 18.53 occurred when drying eggplant slices with thickness $2 \mathrm{~cm}$ and microwave oven power 810 watt.

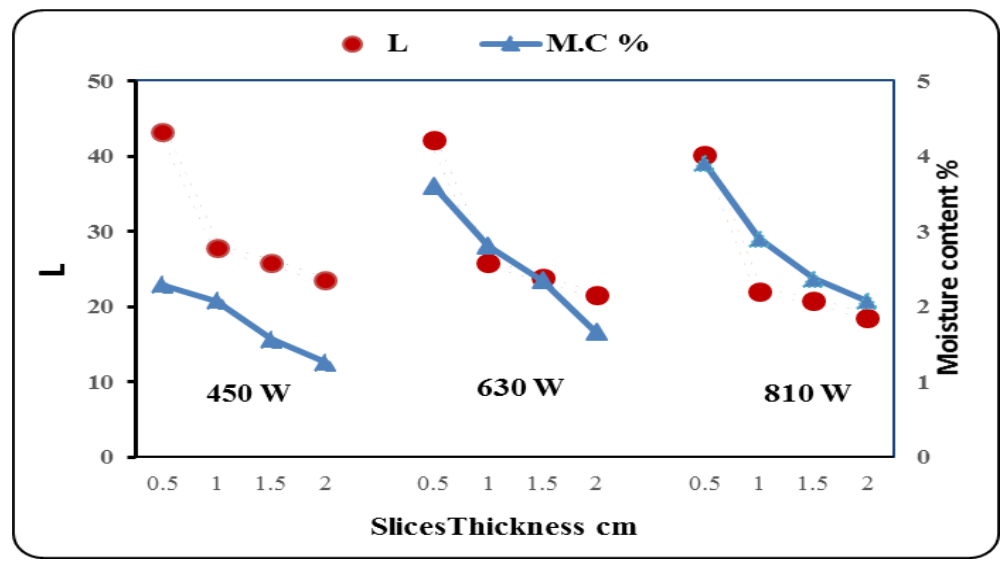

Figure 5: Effect of microwave power on final $L$ value and final moisture content of dried eggplant with different thickness $(0.5,1.0,1.5$ and $2.0 \mathrm{~cm})$.

Figure (7) Effect of microwave power on final (a) value at final moisture content of dried eggplant with different thickness $(0.5,1.0,1.5$ and 2.0 $\mathrm{cm}$ ), from this figure we can obtained that the a value gradually increased by increasing in thickness when use microwave oven at all selected powers, whilst the a value was higher at the higher powers. The higher a value was 13.66 occurred when drying eggplant slices with thickness 2 $\mathrm{cm}$ and microwave oven power 810 watt, but the lower a value was 9.15 occurred when drying eggplant slices with thickness $\cdot .5 \mathrm{~cm}$ and microwave oven power 450 watt. The presented data indicated that, the decreasing of color parameter $\mathrm{L}$ and increasing color parameter a was regular with decreasing moisture content. This result could be due to uniform of drying rate at thickness $0.5 \mathrm{~cm}$ and microwave power $450 \mathrm{~W}$. 


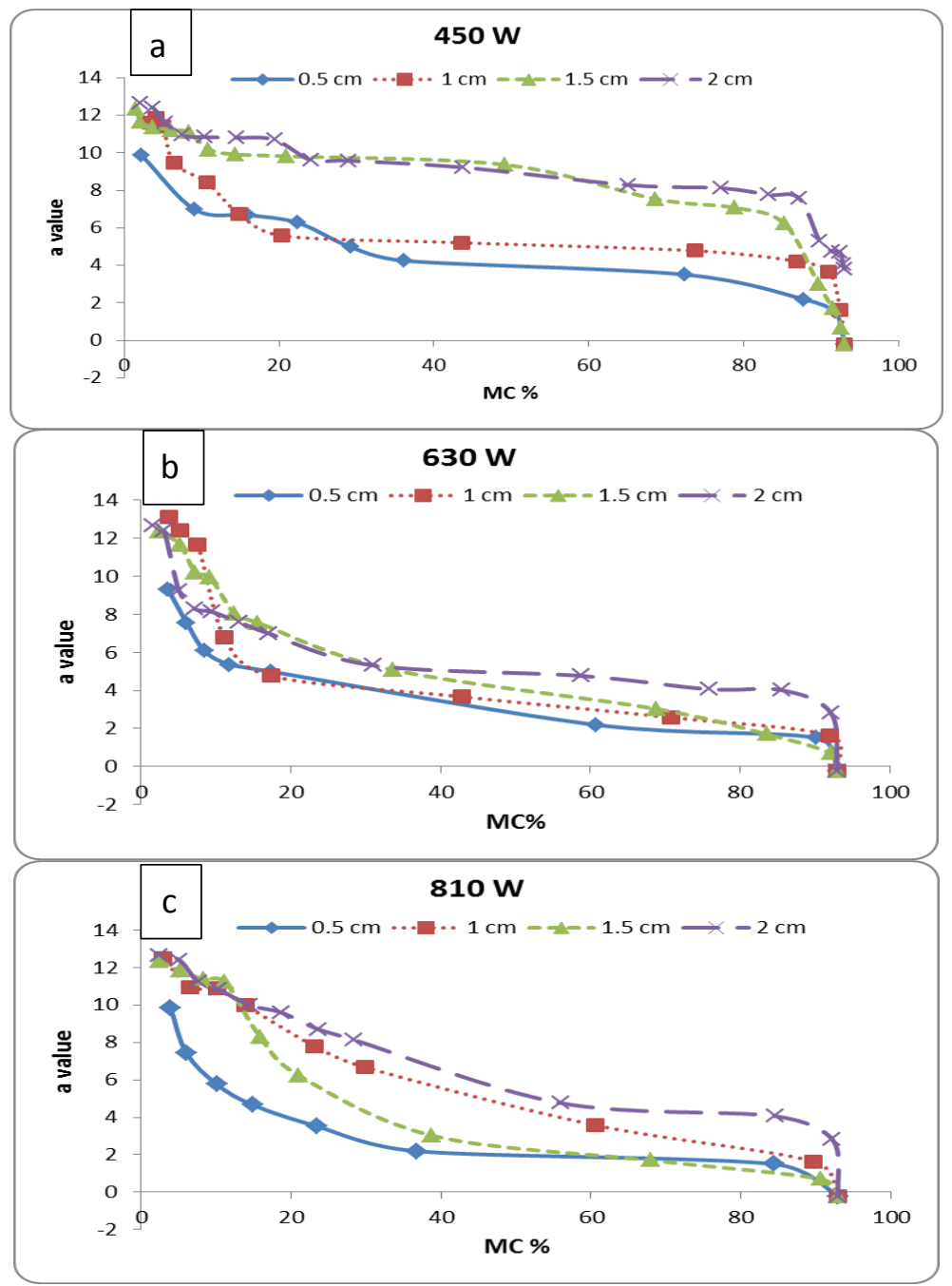

Figure 6 (a, b and c): Effect of microwave power on a value of dried eggplant at different thickness $(0.5,1.0,1.5$ and $2.0 \mathrm{~cm})$

\subsection{Effect of drying on total color change $(\Delta E)$ of eggplant slices}

The results showed that, the effects of microwave powers and thicknesses on final moisture content and total color change $(\Delta \mathrm{E})$ during drying are shown in Figure 8. A larger $\Delta \mathrm{E}$ value represented a greater change in color during drying process. The $\Delta \mathrm{E}$ value used to quantify the color change of the eggplant with the progress of the drying process. The results indicated that, the influence of thickness on $\Delta \mathrm{E}$ was also observed, obtaining a lower value for the samples of lower thickness at $450 \mathrm{~W}$ for microwave power. 


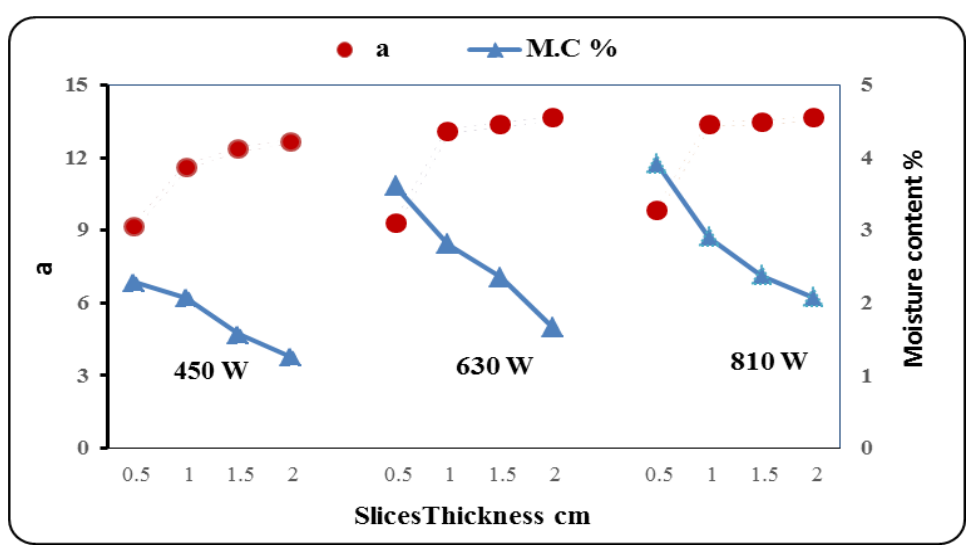

Figure 7 (a, b and c): Effect of microwave power on final (a) value of dried eggplant at different thickness $(0.5,1.0,1.5$ and $2.0 \mathrm{~cm})$.

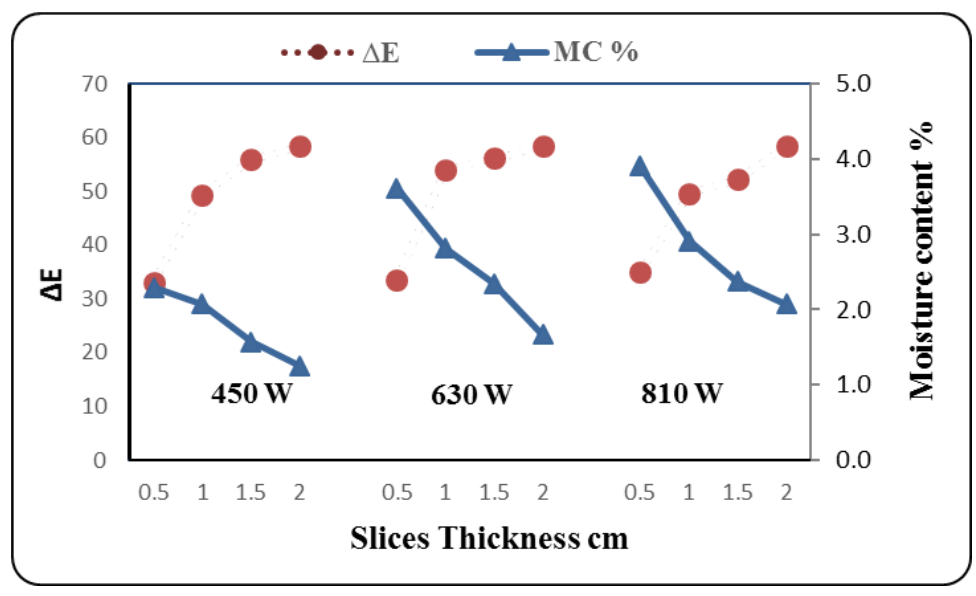

Figure 8: Effect of microwave power on total color change $(\Delta E)$ of dried eggplant at different thickness $(0.5,1.0,1.5$ and $2.0 \mathrm{~cm})$.

The $\Delta \mathrm{E}$ varied from 5.54 to 33.09 at $0.5 \mathrm{~cm}$ of eggplant slices thicknesses and $450 \mathrm{~W}$ of microwave power (this is the lowest value in change compared to the fresh sample). This could be return to the lower microwave power lead to extract water of eggplant slices with uniform rate which has appositive effect on color parameter and total color change. In particular, the sample dried at the $410 \mathrm{~W}$ of microwave power and $0.5 \mathrm{~cm}$ of eggplant thicknesses showed the least color change compared to the fresh sample. Schiffmann (2006) Stated that, microwave power transfers moisture from the interior of the samples to its surface, and this moisture is quickly converted into vapor. 


\subsection{Effect of drying on browning index of eggplant slices}

Figure 10 shows that, the effect of slices thickness and microwave power on browning index. The figure shows that, the browning index increased with increasing slices thickness and microwave power. In addition to, the lowest value of browning index was 121.9 at $450 \mathrm{~W}$ of Microwave power and $0.5 \mathrm{~cm}$ of eggplant slice thickness. The found results of PPO (Polyphenol oxidase) is the key enzyme related to browning in fruits and vegetables. Figure 9 shows that, Eggplant slices color change at $0.5 \mathrm{~cm}$ of slices thickness and $450 \mathrm{~W}$ of microwave power

The result could be due to moisture content return to osmotic dehydration, PPO enzyme might be inactivated due to the heat treatment. Similarly, Mahayothee, et al (2009) found that osmotic dehydration inhibited the PPO activity. Moreover, solute absorption results in lower $\mathrm{O}_{2}$ which is transferred to the surface so browning due to the enzymatic browning is reduced with osmotic dehydration. In addition, during osmotic dehydration, water activity of eggplants (aw) is reduced. In Figure (10), it was clear that, the color changes during drying process at $0.5 \mathrm{~cm}$ of slices thickness and $450 \mathrm{~W}$ of microwave power.
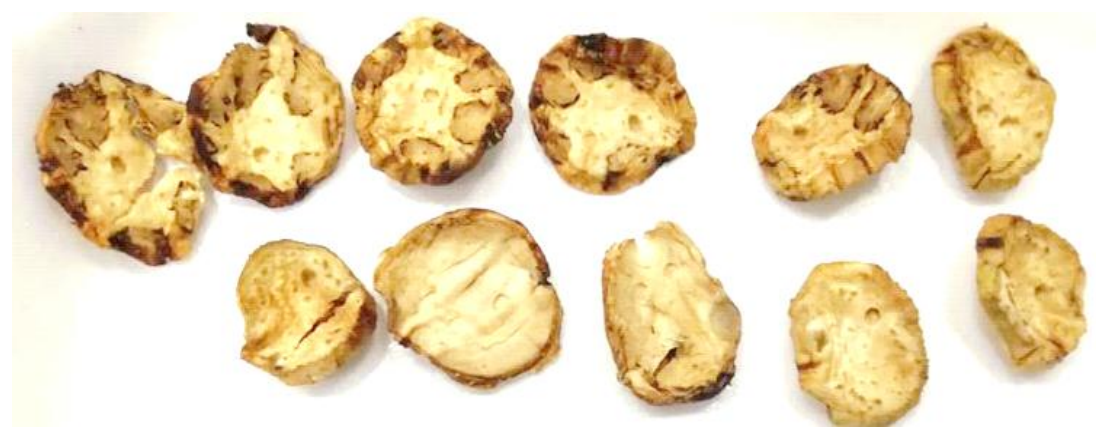

Figure 9: Eggplant slices color change at $0.5 \mathrm{~cm}$ of slices thickness and $450 \mathrm{~W}$ of microwave power.

Figure (11) Effect of microwave power on final (BI) value at final moisture content of dried eggplant with different thickness $(0.5,1.0,1.5$ and $2.0 \mathrm{~cm}$ ), from this figure we can obtained that the $(\mathrm{BI})$ value gradually increased by increasing in thickness when use microwave oven at selected powers for all eggplant thicknesses. The higher (BI) value was 
573.98 occurred when drying eggplant slices with thickness $2 \mathrm{~cm}$ and microwave oven power 810 watt, but the lower (BI) value was 111.93 occurred when drying eggplant slices with thickness. $.5 \mathrm{~cm}$ and microwave oven power 450 watt.

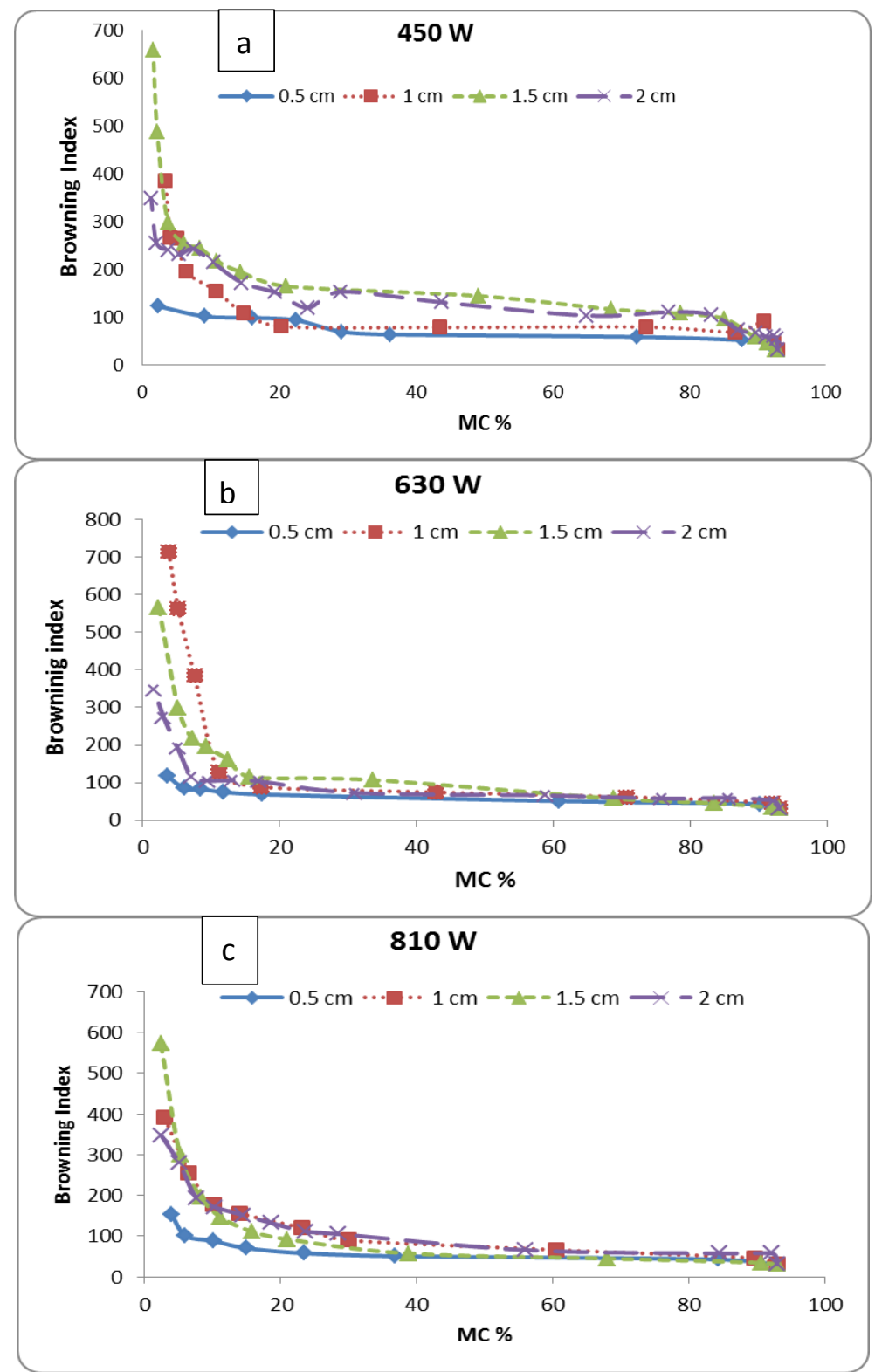

Figure 10: Effect of microwave power on Browning Index of dried eggplant at different thickness $(0.5,1.0,1.5$ and $2.0 \mathrm{~cm})$. 


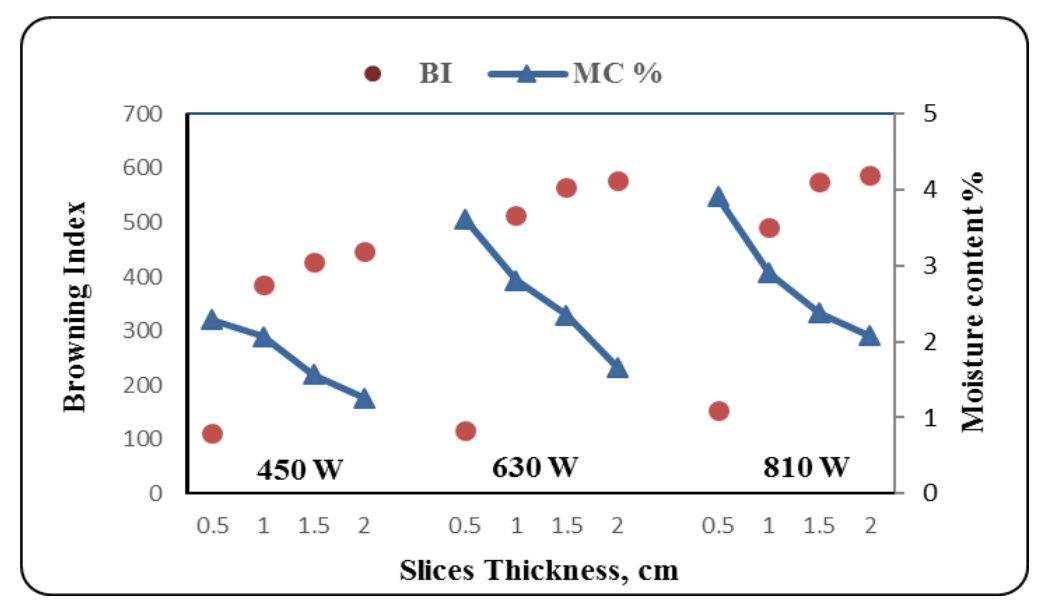

Figure 11: Effect of microwave power on final Browning Index of dried eggplant at different thickness $(0.5,1.0,1.5$ and $2.0 \mathrm{~cm})$.

\subsection{Effect of drying on firmness of eggplant slices}

Figure (12) Effect of microwave power on final firmness value at final moisture content of dried eggplant with different thickness $(0.5,1.0,1.5$ and $2.0 \mathrm{~cm}$ ), from this figure we can obtained that, the final firmness value gradually decreased by increasing in thickness when use microwave oven at selected powers for all eggplant thicknesses. The higher final firmness value was $41.3 \mathrm{~N}$ occurred when drying eggplant slices with thickness $0.5 \mathrm{~cm}$ and microwave oven power 450 watt, but the lower final firmness value was $28.45 \mathrm{~N}$ occurred when drying eggplant slices with thickness $2 \mathrm{~cm}$ and microwave oven power 450 watt.

The firmness of fresh eggplant ranged between 14.72 to $18.25 \mathrm{~N}$ at all slices thicknesses and then decreased gradually with decrease of moisture content for some time; then increased even recorded the highest value at the end of the drying time, at all microwave power for each slices thickness as shown in Figure 13 (a, b, c and d).

After that, the firmness decreased due to the samples became brittle because it lost all moisture content. The initial firmness was $14.72 \mathrm{~N}$ afterward, it decreased to $12.26 \mathrm{~N}$ and then it increased to $44.83 \mathrm{~N}$ and at the end of drying process was $40.22 \mathrm{~N}$ at thickness $0.5 \mathrm{~cm}$ and microwave power $450 \mathrm{~W}$. While, it was $36.4 \mathrm{~N}$ and $30.41 \mathrm{~N}$ at microwave power 630 $\mathrm{W}$ and $810 \mathrm{~W}$ respectively at the end of drying process for thickness 0.5 $\mathrm{cm}$. the similar results were found for other eggplant thickness. 


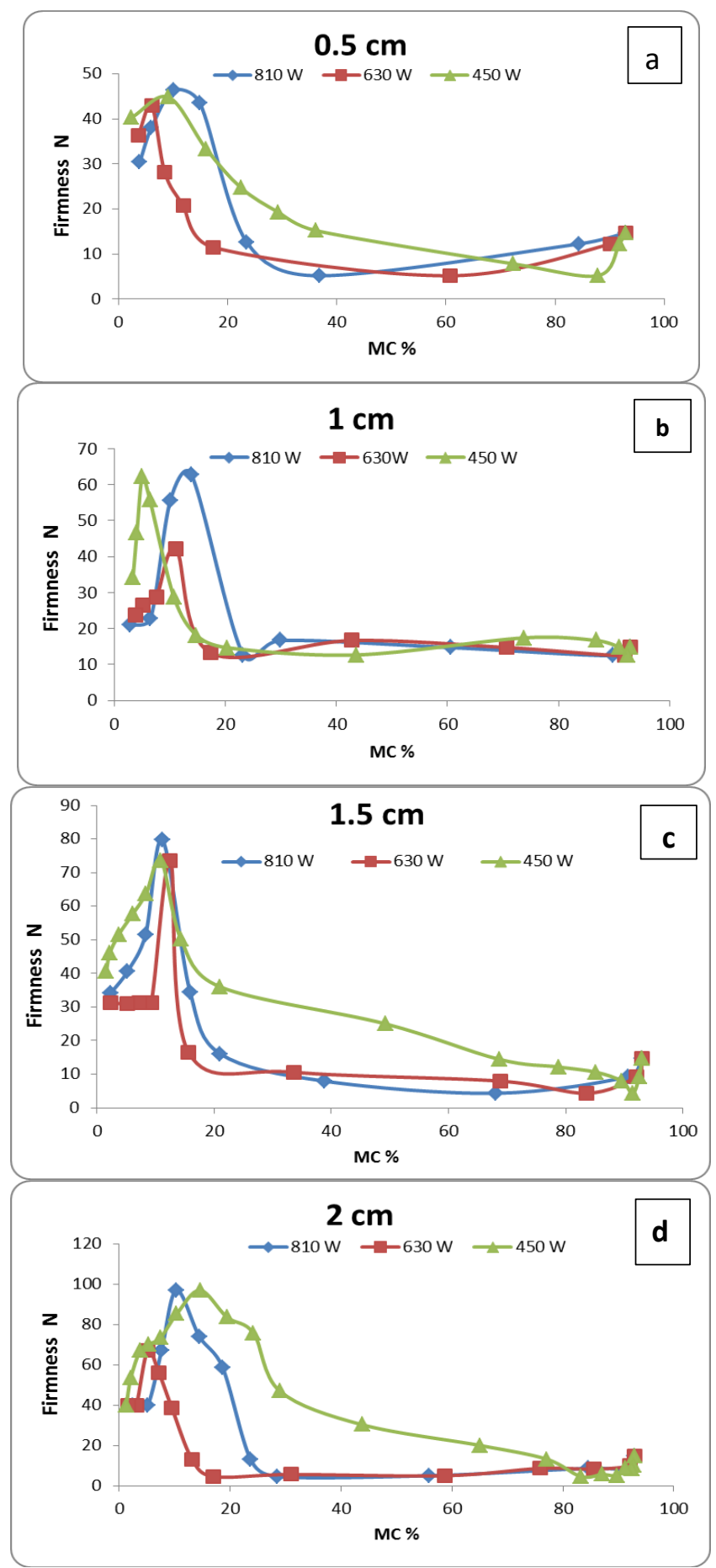

Figure 12: Effect of microwave power on Firmness of dried eggplant at thicknesses $(0.5,1,1.5$ and $2 \mathrm{~cm})$. 


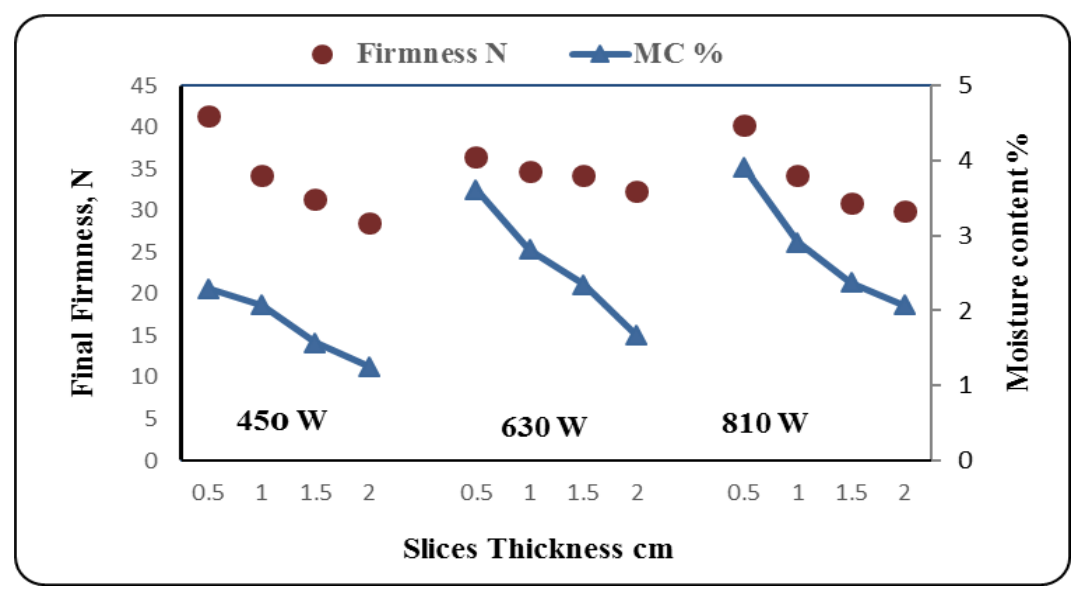

Figure 13: Effect of microwave power on final firmness of dried eggplant at different thickness $(0.5,1.0,1.5$ and $2.0 \mathrm{~cm})$.

\section{4- CONCLUSION.}

Thickness of eggplant and microwave power had a great impact on the color parameter and firmness of the eggplant slices. The lower thickness was lower values of $\Delta \mathrm{E}$ and browning index while it was the highest of the firmness accentuate that, $0.5 \mathrm{~cm}$ of eggplant thickness and $450 \mathrm{~W}$ of microwave power was given the best of eggplant quality properties during drying process.

\section{5- REFERENCE}

AOAC, (1980). Official methods of analysis (13 ${ }^{\text {th }}$ Ed.). Association of official analytical chemists, Washington, D.C.

Bonazzi, C. and Dumoulin, E. (2011) Quality Changes in Food Materials as Influenced by Drying Processes. In: Drying Technology Volume 3: Product Quality and Formulation, First Edition (Edited by Tsotsas, E., Arun, S. and Mujumdar, A.S). Wiley-VCH Verlag GmbH \& Co. KGaA. Published. pp. 1-20

Costa, C., Antonucci, F., Pallottino, F., Aguzzi, J., Sun, D., and Menesatti, P. (2011). Shape analysis of agricultural products: a review of recent research advances and potential application to computer vision. Food and Bioprocess Technology, 4(5), 673692.

Cruz, A. G., and Menegalli, F. C. (2004). Osmotic dehydration and drying of aubergine (Solanum Melongena). Proceedings of the 
14th International Drying Symposium, (pp. 2149-2156). São Paulo.

Deell, J.R., Khanizadeh, S., Saad, F., and Ferree, D.C. (2001) Factors affecting apple fruit firmness: a review. J. Am. Pomol. Soc. 55, $8-$ 27.

Doymaz, İ. (2011) Drying of eggplant slices in thin layers at different air temperatures. Journal of Food Processing and Preservation, 35:280-289.

Doymaz, İ., and Göl, E. (2011). Convective drying characteristics of eggplant slices. Journal of Food Process Engineering, 34:12341252.

Ertekin, C., and Yaldiz, O. (2004). Drying of eggplant and selection of a suitable thin layer drying model. Journal of Food Engineering, 63:349-359.

FAOSTAT. (2013) Production/Crops for Eggplant in 2013. Food and Agriculture Organization of the United Nations, Statistics Division (FAOSTAT). 2015. Retrieved 20 November 2015.

Grossman, R. L., and Wisenblit, J. Z. (1999) What we know about consumers' color choices. Journal of Marketing Practice: Applied Marketing Science, 5(3), 78-88.

Guerra, M. P., Kudo, T., Kon, T. and Holderbaum, D. F. (2010) Enzymatic browning, polyphenol oxidase activity and polyphenols in for apple cultivars: dynamics during fruit development. Hortscience 45(8): 1150 - 1154.

Gunasekaran, S. (1999). Pulsed microwave-vacuum drying of food materials. Drying Technology, 17(3), 395-412.

Jangam, S. V. (2011). An overview of recent developments and some r\&d challenges related to drying of foods. Drying Technology, 29: 1343-1357.

Keshek, M.H., Omar, M.N., and Samak, A.A. (2017). Apple Slices Properties Affecting by Different Drying Methods. The 5th International Conference for Agriculture and Bio Engineering 
"The Role of Agricultural and Biological Engineering for Advancement of the Agricultural Sector" Dokki, Cairo, $26-27$ September 2017 (Conference proceeding part two Pages 357-369).

Leon, K., Mery, D., Pedreschi, F., and Leon, J. (2006) Color measurement in $\mathrm{L}^{*} \mathrm{a}^{*} \mathrm{~b}^{*}$ units from RGB digital images. Food Research International, 39(10), 1084-1091.

Mahayothee, B., Udomkun, P., Nagle, M., Haewsungcharoen, M., Janjai, S., \& Mueller, J. (2009). Effects of pretreatments on colour alterations of litchi during drying and storage. European Food Research and Technology, 229:329-337.

Maskan, M. (2001a) Drying, shrinkage and rehydration characteristics of kiwifruits during hot air and microwave drying. Journal of Food Engineering, 48: 177-182.

Mohamed, M. A.; G. R. Gamea; and M. H. Keshek (2010) "Drying characteristics of okra by different solar dryers". Misr J. Ag. Eng. Vol. 27(1):294 - 312.

Mongi, R.J. (2013) Solar drying of fruits and vegetables: dryers' thermal performance quality and shelf life of dried mango, banana, pineapple and tomato, Ph.D. Thesis., sokoine university of agriculture. Morogoro, Tanzania.

Schiffmann, R.F. (2006) Microwave and dielectric drying. In: Mujumdar AS. (1995) Handbook of industrial drying. ( $\left.2^{\text {nd }} e d\right)$, CRC pres, USA.

Travers, S., (2013) Dry matter and fruit quality manipulation in the field and evaluation with NIR spectroscopy, Ph.D. Thesis., Dept. of Food Science, Faculty of Science and Technology, Aarhus University, Denmark.

Vadivambal, R., and Jayas, D. S. (2007). Changes in quality of microwave-treated agricultural products- a review. Biosystems Engineering, 98:1-16.

Wu, L., Orikasa, T., Ogawa, Y., and Tagawa, A. (2007) Vacuum drying characteristics of eggplants. Journal of Food Engineering, 83: 422-429. 
Zhang, M., and Xu, Y. Y. (2003) Research developments of combination drying technology for fruits and vegetables at home and abroad. Journal of Wuxi University of Light Industry, 22(6), $103 \mathrm{e} 106$.

\section{الملخص العربيى}

\section{التغير فى خواص الجودة للباذنجان أثناء عملية التجفيف بفرن الميكروويف

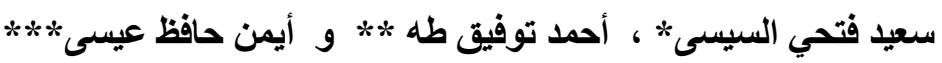

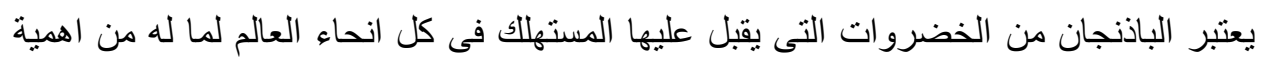

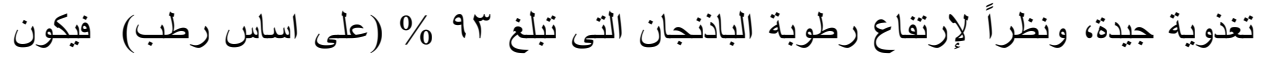

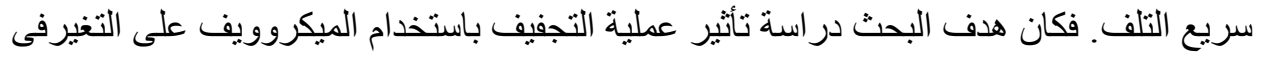

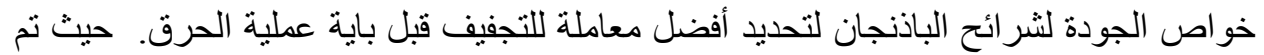

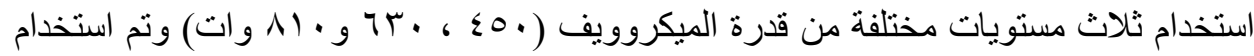

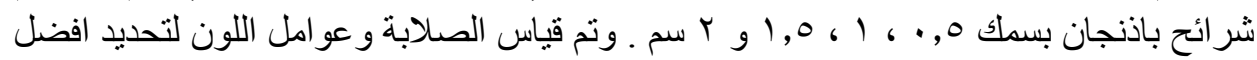

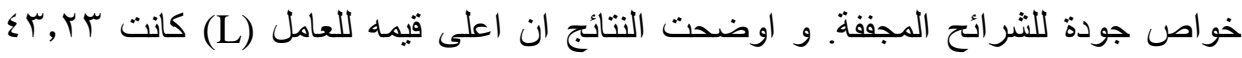

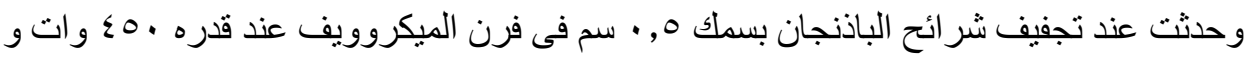

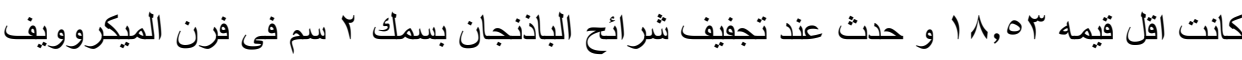

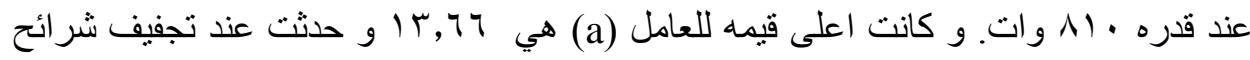

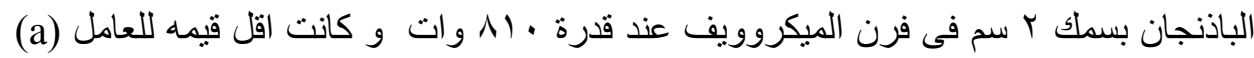

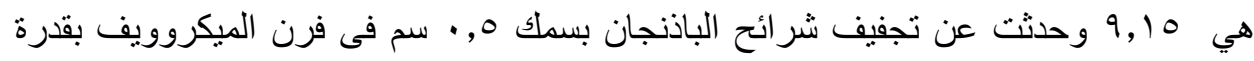

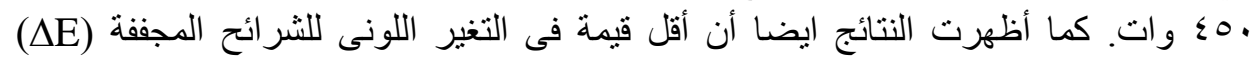

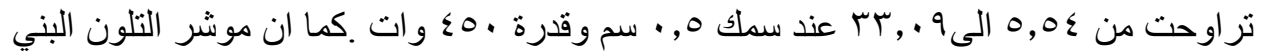
كانت اعلى قيمه له هى

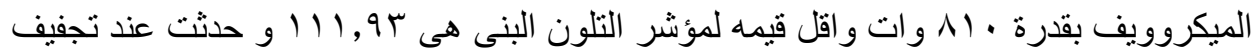

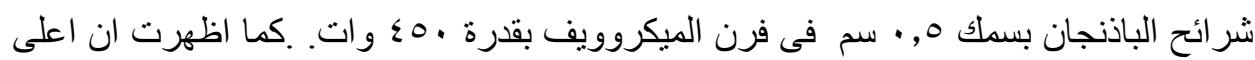

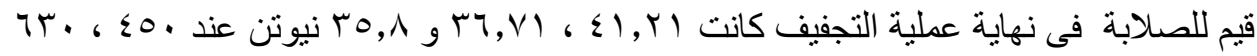
و • 11 وات من قدرات الميكرويف على الترتيب عند سمك 0, · سم من شرائح الباذنجان

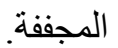

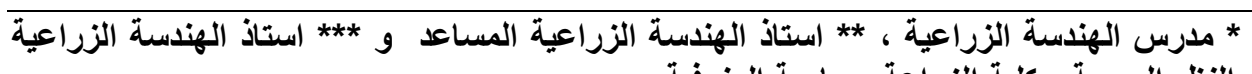

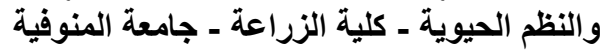

